\title{
Reduced metabolic rate and increased heart beat as early signs of sub lethal Copper toxicity in developing Zebrafish
}

\author{
Evangelia Gouva ${ }^{1,2 *}$, Cosmas Nathanailides ${ }^{1}$, Ioannis Paschos ${ }^{1}$, Fotini Athanassopoulou ${ }^{2}$, Ioannis S. Pappas ${ }^{2}$ \\ ${ }^{1}$ Faculty of Agriculture, University of Ioannina, Kostakioi Arta, 47100, Arta, Greece \\ ${ }^{2}$ Faculty of Veterinary Medicine, University of Thessaly, Trikalon str. 224, 43100 Karditsa, Greece
}

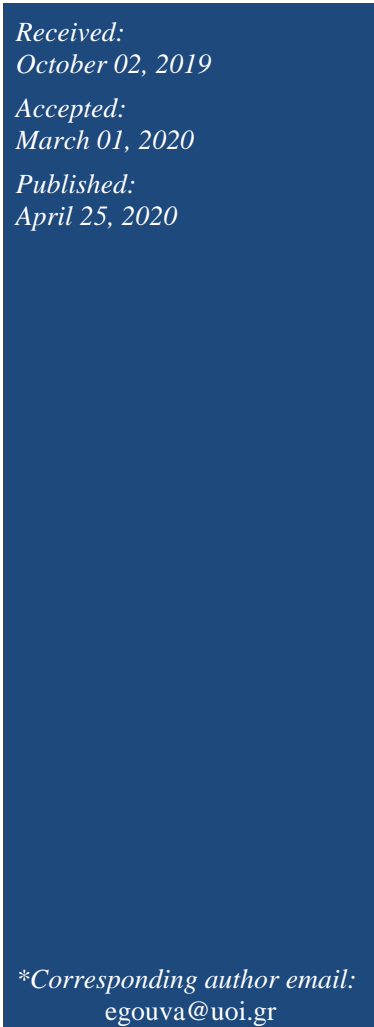

\section{Abstract}

The current study looks at acute and sub-lethal Copper toxicity on developing zebrafish embryos up to 96 hours post fertilisation (PSF). We allocated four-hour PSF zebrafish embryos in four groups with duplicates, and $500 \mathrm{mg}, 50 \mathrm{mg}$, and $0.05 \mathrm{mg} \mathrm{l}^{-1}$ and a control group for 96 hours PSF. All fish exposed to $500 \mathrm{mg} \mathrm{l}^{-1}$ copper died within the first 6 hours PSF. Significant sub-lethal copper toxic effects on developing Zebrafish were manifested in the 0.05 and the $50 \mathrm{mg}$ groups, by increased heartbeat rate within the first 25 hours PSF in the 0.05 and $50 \mathrm{mg}$ group. The sub-lethal toxic effect was also manifested in the metabolism of developing embryos, with a reduced rate of utilisation of yolk and lower growth rate and anatomical malformations within the first 25 hours in the $50 \mathrm{mg}$ group and after 50 hours PSF in both the 0.05 and $50 \mathrm{mg}$ group. The results indicate that reduced metabolic rate and increased heartbeat rate are potential early signs of sub-lethal $\mathrm{Cu}$ toxicity in developing Zebrafish well before other developmental defects are visually evident.

Keywords: Toxicity, Development, Fish, Metabolism

\section{How to cite this:}

Gouva E, Nathanailides C, Paschos I, Athanassopoulou F and Pappas IS, 2020. Reduced metabolic rate and increased heart beat as early signs of sub lethal Copper toxicity in developing Zebrafish. Asian J. Agric. Biol. 8(2): 119-128.

DOI: https://doi.org/10.35495/ajab.2019.09.415

This is an Open Access article distributed under the terms of the Creative Commons Attribution 3.0 License. (https://creativecommons.org/licenses/by/3.0), which permits unrestricted use, distribution, and reproduction in any medium, provided the original work is properly cited.

\section{Introduction}

Aquatic ecosystems may exhibit a range of pollutants with an anthropogenic origin, including heavy metals. Even at concentrations not alarming for humans, heavy metals may have a significant effect on aquatic life (Milanov et al., 2016). In the early stages of their life cycle, fish are, especially susceptible to heavy metals (Linbo et al., 2006). Copper $(\mathrm{Cu})$ is found in nature and is a major trace element for vertebrates (Mount, 1968). However, in higher concentration, $\mathrm{Cu}$ becomes toxic (Flemming and Trevors, 1989), with effects on fish organs (Bashir et al., 2018). Waterborne $\mathrm{Cu}$ decreases the swimming potential and metabolism considerably, even at small levels (De Boeck et al., 2006). Dave and Xiu (1991) in their experimental study, concluded that $\mathrm{Cu}$ and nickel are major inhibitors of zebrafish embryonic hatching compared to cobalt, led, and mercury. Also, the literature asserts that adult fish are less susceptible to heavy metal toxicity in comparison with the larvae (Von Westernhagen, 1988) resulting in significant 
effects on larval health (Hernandez et al., 2011; Finn, 2007).

The effect of toxic compounds may vary according to different stages of development (Jezierska et al., 2009). For example, in early life stages, the most vulnerable and crucial periods for larvae are the first stages of embryonic development and subsequently, the hatching stage (Gellert and Heinrichsdorff, 2001). Heavy metals of environment can cause acute toxicity to zebrafish, whose effects associated varies according to different embryonic stages of development (Yang et al., 2016).

The use of a range of anatomical, biochemical, and viability indicators are useful in assessing the toxic effect of enhanced concentrations of $\mathrm{Cu}$ on developing embryos (Parichy et al., 2009). Heartbeat rate is one of the parameters affected by heavy metals and has the potential to be widely and easily used for toxicological research on developing zebrafish embryos (Kang et al., 2018). It is a reliable method for piloting experimental work required for designing toxicological experiments, such as selecting a potentially toxic agent and its concentration for further research. Also, the heartbeat rate is a reliable indicator of the functional status of this organ (Rubinstein, 2006; Yang et al., 2016). Heavy metals like $\mathrm{Cu}$ can affect heartbeat rate of fish embryos (Mu et al., 2013) with a variable magnitude according to the concentration of the toxic compound tested (Suvarchala and Philip, 2016; Yang et al., 2016). Sighting or dose-ranging studies are widely used as pilots for experimental work in toxicological research providing a rapid assessment of the experimental dosage for usage in the main experimental work (Stallard et al., 2003; Mielke et al., 2017).

Copper, as a trace element has an essential role in the physiology of embryonic development (Lee et al., 2001; Mackenzie et al., 2004) but in excess quantities, it has negative effects on the metabolism and development of fish (Johnson et al., 2007). The present experimental work aimed to assess the potential use of heartbeat rate for the initial evaluation of waterborne $\mathrm{Cu}$ exposure on zebrafish embryonic development and survival. For this reason, we monitored the survival rate and a range of anatomical malformations and heartbeat rate in developing zebrafish embryos exposed to different levels of $\mathrm{Cu}$.

\section{Material and Methods}

We conducted experiments between March 2018 and
January 2019 at the Department of Agricultural Sciences, University of Ioannina. The experiments observed the fish welfare recommendations of the Faculty of Veterinary Medicine, University of Thessaly.

\section{Experimental animals and reproduction of zebrafish}

Adult zebrafish were acclimated and maintained in 10 liter aquaria at $28.5^{\circ} \mathrm{C}$. All parent zebrafish were aged about 3-month old. We fed the fish ad libitum and under a photoperiod of 12 hours with male and female (ratio $300^{\lambda}: 15$ ) broodstock fish kept in separately before the breeding day. The eggs were collected the next day early in the morning, within 1 hour after turning on the lights. We placed the viable eggs in standard zebrafish hatchery water (Brand et al., 2002). Water parameters that were monitored daily included temperature $\left(29 \pm 1^{\circ} \mathrm{C}\right), \mathrm{NO}_{\mathrm{X}}$, with $\mathrm{NO}_{2}$ and $\mathrm{NO}_{3}$ remained at low levels $\left(<0.01 \mathrm{mg} \mathrm{l}^{-1}\right.$ and $<100 \mathrm{mg} \mathrm{l}^{-1}$, respectively), $\mathrm{NH}_{\mathrm{X}}$, with $\mathrm{NH}_{3}$ and $\mathrm{NH}_{4}$ remained low levels $\left(<0.009 \mathrm{mg} \mathrm{l}^{-1}\right.$ and $<0.5 \mathrm{mg} \mathrm{l}^{-1}$, respectively). General hardness ranged between $7^{\circ}$ and $14^{\circ}$, and Carbonate hardness was $6^{\circ}$ and, $\mathrm{pH}$ ranged between 7.2 and 7.3.

Using a stereoscope randomly selected fertilised eggs ( 2 or 4 cell-stage zebrafish) were placed in glass Petri dishes floating in experimental tanks. Subsequently, the eggs were divided in the different experimental groups and replicated $(n=15$ per replicate) and placed in plate Corning® wells (24-well) containing the different experimental dilutions of $\mathrm{Cu}$ sulphate.

\section{Copper exposures}

In a pilot experiment carried out in our laboratory, the $\mathrm{LC}_{50}$ value of $\mathrm{Cu}$ for embryonic stages of zebrafish, the results showed $0.075 \mathrm{mg} \mathrm{l}^{-1}$ (Gouva et al., 2019). In the present work, test solution preparation included as needed with a series of dilutions using Copper sulphate- $\mathrm{CuSO}_{4}$. The current work includes duplicate control and experimental groups.

\section{Monitored parameters up 96 hours after hatching} In each location, we used a Corning ${ }^{\circledR}$ plate (24-well) initially placed with successive diluted solutions of $\mathrm{Cu}$ were fertilised eggs were immersed. We consequently monitored all fertilised eggs (duplicates of 15 fertilised eggs for each treatment) during the following stages of exposure for observable sub-lethal effect and mortality. The duration of $\mathrm{Cu}$ exposure was 96 hours. The Corning ${ }^{\circledR}$ plates (24-well) were semi 
immersed/floating in aquarium tanks where the temperature remained constant at $30^{\circ} \mathrm{C}$ using a temperature-controlled system with automatic thermostats. In the first 48 hours, observations and recordings took place every 6 hours, while in the next 48 hours they took place every 12 hours using a digital camera (Motic $\mathrm{B}_{1}$ series, Motic China Group Co, ) and a stereoscope (Motic SMZ-168 series, Motic China Group Co) with a built-in camera. We measured the anatomical features to the nearest $1 \mathrm{~mm}$. Total length (TL) and estimated the yolk sack volume from samples obtained at 25, 50, and 75 hours after fertilisation ( $n=6$ from each group). We calculated the yolk sack volume $(V)$ in accordance to the ellipsis equation: $V=4 / 3 * \pi *(a / 2) *(b / 2)^{2}(a$ : max Length of yolk, $b$ : max Width of yolk).

\section{Heartbeat rate}

For the needs of measuring the heart rate, we selected three larvae at random for each experimental group to which we carried out repeated measurements. The heart rate measurement was performed 6 hours after hatching for each experimental group, according to the methodology described by Barrionuevo et al. (2010). During the measurement, water temperature was kept at $28^{\circ} \mathrm{C}$ using a room temperature control unit. For greater accuracy in recording the measurement of heart rate of the selected larvae, we used a digital camera. We determined the heart rate by calculating the number of heartbeats from 20 to 30 seconds periods and subsequently we converted these values to heart rate in beats per minute, based on data from triplicate measurements for each sample of each duplicate.

\section{Statistical analysis}

To assess the effects of different exposure dilutions, we used Kruskal-Wallis non-parametric test after failing normality assumptions based on the ShapiroWilk test. Non-parametric post hoc tests followed to determine significance among the different groups. Cox regression analysis was applied to examine differences in hatching time and survival times among the different $\mathrm{Cu}$ dilution groups. All presented results have $95 \%$ confidence intervals (CI) and statistical significance is set at $p<0.05$. All analyses carried out using SPSS v23.0.

\section{Results}

\section{Anatomical malformations}

Exposure to $\mathrm{Cu}$ resulted in anatomical malformations which included abnormal formation of spinal curvature, pericardial edema, undeveloped lower jaws, and uninflated swim bladder. At 52 and 75 hours PSF, embryos of zebrafish larva of the $0.05 \mathrm{mg}^{-1} \mathrm{Cu}$ exposure, exhibited posterior body scoliosis, dysplastic yolk sac, abnormal fattening of their posterior part, and severe pericardial edema. We did not observe these manifestations in the previous sample obtained at 36 hours PSF. At 60 hours post fertilisation (PSF) larvae of the $50 \mathrm{mg} \mathrm{l}^{-1} \mathrm{Cu}$ exposure exhibited severe scoliotic middle skeletal portion, a curvature of caudal part and caudal tip malformation, full spine curvature, and caudal crus shortening. In particular, in the experimental group of $50 \mathrm{mg} \mathrm{l}^{-1} \mathrm{Cu}$ we observed one larva with skeletal problems, while in the experimental group of $0.05 \mathrm{mg} \mathrm{l}^{-1} \mathrm{Cu}$ we observed two larvae with skeletal problems.

\section{Survival curves for time to hatching after $\mathrm{Cu}$ exposure and Hazard to death}

Table 1 presents the hatching curves after $\mathrm{Cu}$ exposure. The survival curve regarding hatching showed that $\mathrm{Cu}$ affects hatching time. Cox regression analysis (Table 1) indicates that the greater the $\mathrm{Cu}$ concentration, the greater the hazard of non-hatching. More particularly, the analysis showed that the hazard ratio of non-hatching is 4.01 times higher $(95 \%$ C.I.:1.97-8.14) in the $50 \mathrm{mg} \mathrm{l}^{-1}$ group and 1.96 times higher (95\% C.I.:1.12-3.43) in the $0.05 \mathrm{mg} \mathrm{l}^{-1}$ group compared to the control group. These two groups also differ from one another with a hazard ratio of 2.04 (95\% C.I.:1.04-4.01) higher hazard of non-hatching in the $50 \mathrm{mg}^{-1}$ group compared to the $0.05 \mathrm{mg} \mathrm{l}^{-1}$ group. Figure 1 presents the survival curves for time to hatching by type of $\mathrm{Cu}$ dilution for the control group and dissolved $\mathrm{Cu}$ group. 
Evangelia Gouva et al.

Table-1: Survival curves for time to hatching after copper exposure and Cox regression analysis on types of copper dilution for hatching time.

\begin{tabular}{|c|c|c|c|c|c|c|c|c|c|c|c|c|}
\hline \multirow{4}{*}{ Treatment } & \multicolumn{4}{|c|}{ Case Processing Summary } & \multirow{2}{*}{\multicolumn{4}{|c|}{$\begin{array}{c}\begin{array}{c}\text { Means and Medians for } \\
\text { Survival Time }\end{array} \\
\text { Mean }^{\mathrm{a}} \\
\end{array}$}} & \multirow{2}{*}{\multicolumn{4}{|c|}{ Overall Comparisons }} \\
\hline & \multirow{3}{*}{$\begin{array}{c}\text { Total } \\
\mathrm{N}\end{array}$} & \multirow{3}{*}{$\begin{array}{l}\mathrm{N} \text { of } \\
\text { Events }\end{array}$} & & Eensored & & & & & & & & \\
\hline & & & \multirow{2}{*}{$\mathrm{N}$} & \multirow{2}{*}{ Percent } & \multirow{2}{*}{ Estimate } & \multirow{2}{*}{$\begin{array}{l}\text { Std. } \\
\text { Error }\end{array}$} & \multicolumn{2}{|c|}{\begin{tabular}{|c|}
$\begin{array}{c}95 \% \text { Confidence } \\
\text { Interval }\end{array}$ \\
\end{tabular}} & & $\begin{array}{c}\text { Chi- } \\
\text { Square }\end{array}$ & df & Sig. \\
\hline & & & & & & & $\begin{array}{l}\text { Lower } \\
\text { Bound } \\
\end{array}$ & $\begin{array}{l}\text { Upper } \\
\text { Bound } \\
\end{array}$ & $\begin{array}{c}\text { Log Rank } \\
\text { (Mantel-Cox) } \\
\end{array}$ & 26.697 & 2 & .000 \\
\hline Control Group & 28 & 28 & 0 & $.0 \%$ & 32.464 & 1.076 & 30.356 & 34.573 & \multirow{4}{*}{\multicolumn{4}{|c|}{$\begin{array}{l}\text { Test of equality of survival } \\
\text { distributions for the different } \\
\text { levels of type of copper dilution. }\end{array}$}} \\
\hline Copper $50 \mathrm{mg} \mathrm{l}^{-1}$ & 16 & 16 & 0 & $.0 \%$ & 48.188 & 3.280 & 41.758 & 54.617 & & & & \\
\hline Copper $0.05 \mathrm{mg} \mathrm{l}^{-1}$ & 26 & 26 & 0 & $.0 \%$ & 37.808 & 1.432 & 35.002 & 40.613 & & & & \\
\hline Overall & 70 & 70 & 0 & $.0 \%$ & 38.043 & 1.230 & 35.632 & 40.454 & & & & \\
\hline \multirow{2}{*}{\multicolumn{5}{|c|}{ Treatment }} & \multirow{2}{*}{\multicolumn{2}{|c|}{$\mathrm{p}$}} & \multirow{2}{*}{\multicolumn{2}{|c|}{$\mathrm{HR}$}} & \multicolumn{4}{|c|}{$95,0 \% \mathrm{CI}$ for $\mathrm{HR}$} \\
\hline & & & & & & & & & Lower & \multicolumn{3}{|c|}{ Upper } \\
\hline \multicolumn{5}{|c|}{ Copper $50 \mathrm{mg}$ 1-1 vs Control Group } & \multicolumn{2}{|c|}{.000} & \multicolumn{2}{|c|}{4.01} & 1.97 & \multicolumn{3}{|c|}{8.14} \\
\hline \multicolumn{5}{|c|}{ Copper $0.05 \mathrm{mg} \mathrm{l}^{-1}$ vs Control Group } & \multicolumn{2}{|c|}{.018} & \multicolumn{2}{|c|}{1.96} & 1.12 & 3.4 & & \\
\hline \multicolumn{5}{|c|}{ Copper $50 \mathrm{mg} \mathrm{l}^{-1} \mathrm{vs}^{2}$ Copper $0.05 \mathrm{mg} \mathrm{l}^{-1}$} & \multicolumn{2}{|c|}{.038} & \multicolumn{2}{|c|}{2.04} & 1.04 & \multicolumn{3}{|c|}{4.01} \\
\hline
\end{tabular}

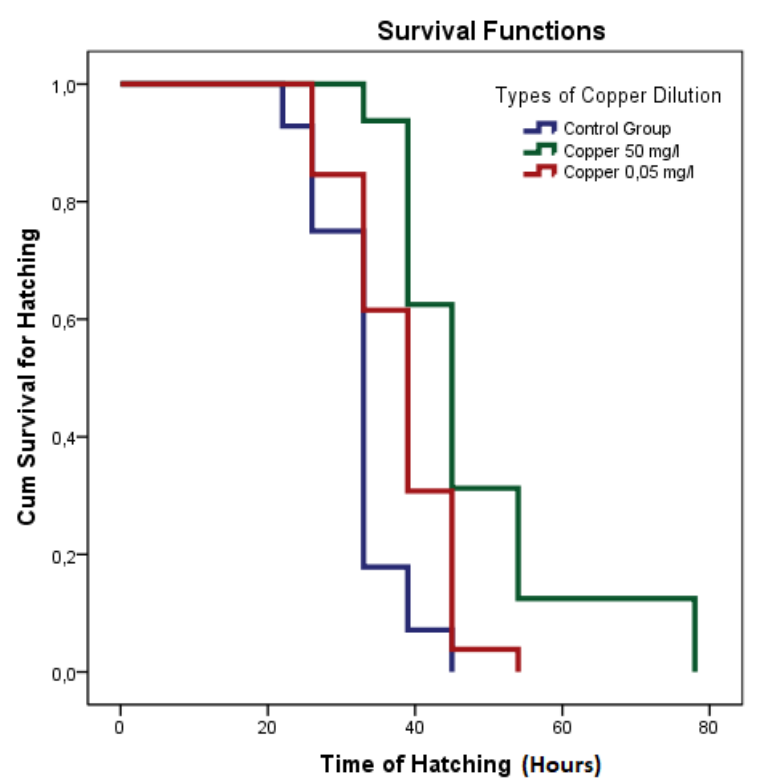

Figure-1: Post-hatching survival curves of zebrafish exposed to copper.

Survival of embryos and larvae and hazard to death up to 96 hours PSF

Table 2 presents the viability of fertilised eggs during embryonic and larval development. In the $500 \mathrm{mg} \mathrm{l}^{-1}$ group, we observed total mortality of the fertilised eggs. At the same time, we observed $36.7 \%$ and $10.0 \%$ mortality in 0.05 and $50 \mathrm{mg} \mathrm{l}^{-1}$ groups, respectively. Over the entire period of 96 hours PSF, the control and $0.05 \mathrm{mg} \mathrm{l}^{-1}$ fish had similar viability, but the embryos exposed to $50 \mathrm{mg}^{-1}$ copper showed significantly lower viability compared to them.

Hazard analysis of the results provided some important information for the hazard of embryos exposed to $\mathrm{Cu}$. Survival curves (Table 2) show that $\mathrm{Cu}$ is affected in developing embryos and larval viability after each exposure time. Cox regression analysis (Table 2) showed that the greater the $\mathrm{Cu}$ concentration, the greater the hazard of death. In particular, the analysis showed that compared to the control, the hazard ratio was 21.34 times higher (95\% C.I.:6.1174.50) when we exposed the fish to $500 \mathrm{mg} \mathrm{l}^{-1} ; 6.20$ times higher (95\% C.I.:2.76-13.96) when we exposed the fish to 0.05 ; and 3.07 times higher (95\% C.I.:1.576.02) in the $50 \mathrm{mg} \mathrm{l}^{-1}$ fish group. The $50 \mathrm{mg} \mathrm{l}^{-1}$ group also has a significantly higher hazard ratio compared to the control group 6.94 (95\% C.I.:2.01-23.94). Differences between the $\mathrm{Cu} 0.05 \mathrm{mg} \mathrm{l}^{-1}$ group and the control group as well as differences between the $\mathrm{Cu} 50$ $\mathrm{mg}^{-1}$ and the $\mathrm{Cu} 0.05 \mathrm{mg} \mathrm{l}^{-1}$ group were borderline non-significant ( $p=0.061$ and 0.084 , respectively) and 1.96 times higher (95\% C.I.:1.12-3.43) in the $0.05 \mathrm{mg}$ $1^{-1}$ group compared to the control group. The two groups further differ from one another with a hazard ratio of 2.04 (95\% C.I.:1.04-4.01) higher hazard of non-hatching in the $50 \mathrm{mg} \mathrm{l}^{-1}$ group compared to the $0.05 \mathrm{mg} \mathrm{l}^{-1}$ group. The control group of survival times and dissolved $\mathrm{Cu}$ groups at 500, 50, and $0.05 \mathrm{mg} \mathrm{l}^{-1}$ are significantly different. 
Evangelia Gouva et al.

Table-2: Survival curves for time to death after copper exposure and Cox regression analysis for lifetime after copper exposure.

\begin{tabular}{|c|c|c|c|c|c|c|c|c|c|c|c|c|}
\hline \multirow{4}{*}{ Treatment } & \multicolumn{4}{|c|}{ Case Processing Summary } & \multirow{2}{*}{\multicolumn{4}{|c|}{$\begin{array}{c}\begin{array}{c}\text { Means and Medians for } \\
\text { Survival Time }\end{array} \\
\text { Mean }^{\mathrm{a}}\end{array}$}} & \multirow{2}{*}{\multicolumn{4}{|c|}{ Overall Comparisons }} \\
\hline & \multirow{3}{*}{$\begin{array}{c}\text { Total } \\
\mathrm{N}\end{array}$} & \multirow{3}{*}{$\begin{array}{c}\mathrm{N} \\
\text { of Events }\end{array}$} & \multicolumn{2}{|c|}{ Censored } & & & & & & & & \\
\hline & & & \multirow[b]{2}{*}{$\mathrm{N}$} & \multirow{2}{*}{ Percent } & \multirow{2}{*}{ Estimate } & \multirow{2}{*}{$\begin{array}{l}\text { Std. } \\
\text { Error }\end{array}$} & \multicolumn{2}{|c|}{ 95\% Confidence Interval } & & $\begin{array}{c}\text { Chi- } \\
\text { Saure }\end{array}$ & df & Sig. \\
\hline & & & & & & & Lower Bound & $\begin{array}{l}\text { Upper } \\
\text { Bound }\end{array}$ & $\begin{array}{c}\text { Log Rank } \\
(\text { Mantel-Cox) }\end{array}$ & 74.709 & 3 & .000 \\
\hline Control Group & 30 & 3 & 27 & $90.0 \%$ & 89.467 & 4.321 & 80.997 & 97.936 & \multirow{5}{*}{\multicolumn{4}{|c|}{$\begin{array}{l}\text { Test of equality of survival } \\
\text { distributions for the different } \\
\text { levels of type of copper } \\
\text { dilution. }\end{array}$}} \\
\hline Copper $500 \mathrm{mg} \mathrm{l}^{-1}$ & 30 & 30 & 0 & $.0 \%$ & 1.000 & .000 & 1.000 & 1.000 & & & & \\
\hline Copper $50 \mathrm{mg} \mathrm{l}^{-1}$ & 30 & 16 & 14 & $46.7 \%$ & 52.967 & 8.123 & 37.046 & 68.887 & & & & \\
\hline Copper $0.05 \mathrm{mg} \mathrm{l}^{-1}$ & 30 & 10 & 20 & $66.7 \%$ & 83.833 & 5.248 & 73.547 & 94.119 & & & & \\
\hline Overall & 120 & 59 & 61 & $50.8 \%$ & 56.817 & 4.156 & 48.670 & 64.963 & & & & \\
\hline \multirow{2}{*}{\multicolumn{5}{|c|}{ Treatment }} & \multirow{2}{*}{\multicolumn{2}{|c|}{$\mathrm{p}$}} & \multirow{2}{*}{\multicolumn{2}{|c|}{ HR }} & \multicolumn{4}{|c|}{$95,0 \% \mathrm{CI}$ for $\mathrm{HR}$} \\
\hline & & & & & & & & & Lower & & pper & \\
\hline \multicolumn{5}{|c|}{ Copper $500 \mathrm{mg} \mathrm{l}^{-1}$ vs Control Group } & \multicolumn{2}{|c|}{.000} & \multicolumn{2}{|c|}{21.34} & 6.11 & & 4.50 & \\
\hline \multicolumn{5}{|c|}{ Copper $50 \mathrm{mg} \mathrm{l}^{-1}$ vs Control Group } & \multicolumn{2}{|c|}{.002} & \multicolumn{2}{|c|}{6.94} & 2.01 & & 3.94 & \\
\hline \multicolumn{5}{|c|}{ Copper $0.05 \mathrm{mg} \mathrm{l}^{-1}$ vs Control Group } & \multicolumn{2}{|c|}{.061} & \multicolumn{2}{|c|}{3.44} & 0.95 & & 2.50 & \\
\hline \multicolumn{5}{|c|}{ Copper $500 \mathrm{mg} \mathrm{l}^{-1}$ vs Copper $0.05 \mathrm{mg} \mathrm{l}^{-1}$} & \multicolumn{2}{|c|}{.000} & \multicolumn{2}{|c|}{6.20} & 2.76 & & 3.96 & \\
\hline \multicolumn{5}{|c|}{ Copper $50 \mathrm{mg} \mathrm{l}^{-1}$ vs Copper $0.05 \mathrm{mg} \mathrm{l}^{-1}$} & \multicolumn{2}{|c|}{.084} & \multicolumn{2}{|c|}{2.02} & 0.91 & & .47 & \\
\hline \multicolumn{5}{|c|}{ Copper $500 \mathrm{mg} \mathrm{l}^{-1} \mathrm{vs}$ Copper $50 \mathrm{mg} \mathrm{l}^{-1}$} & \multicolumn{2}{|c|}{.001} & 3.07 & & 1.57 & & .02 & \\
\hline
\end{tabular}

\section{Growth and metabolism}

Figure 2 presents the growth in length of the developing larvae. Growth and development of the 0.05 and the $50 \mathrm{mg} \mathrm{l}^{-1}$ groups were affected by $\mathrm{Cu}$. Growth of the control fish was significantly higher compared to the 0.05 and the $50 \mathrm{mg} \mathrm{l}^{-1}$ group.

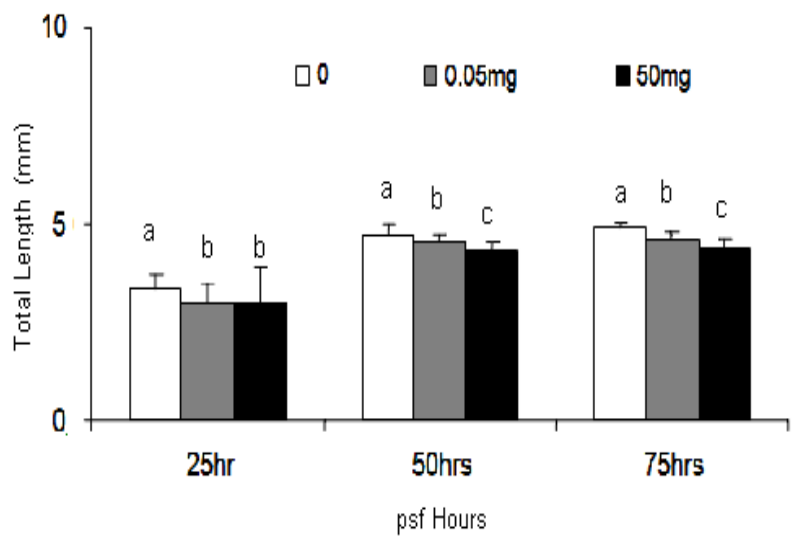

Figure-2. Effect of copper on the growth rate of zebrafish embryonic and larval stages of development.

At 25, 50 and 75 hours, TL of the controlled growth was significantly longer than the 0.05 and the $50 \mathrm{mg}$ $1^{-1}$ fish group $(p<0.05)$, but there was no significant difference between 0.05 and $50 \mathrm{mg}$ groups at 25 hours PSF.
$\mathrm{Cu}$ affected the metabolism of the developing larvae. Gradually after hatching, the fish of the control group utilised at a higher rate, the reserves of their yolk sack. The difference between the control and the $\mathrm{Cu}$ exposed group was more pronounced in the $50 \mathrm{mg} \mathrm{l}^{-1}$ group (Fig. 3).

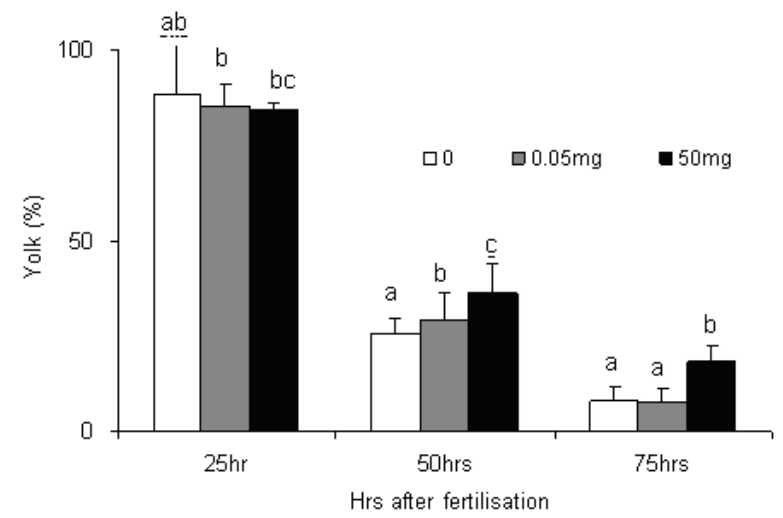

Figure-3: Cu effects on the embryonic metabolism as indicated by the yolk absorption rate

( $Y$ axis indicates the amount of remaining yolk reserves as \%) during embryonic and larval development of Zebrafish. All monitored stages (25, 50 and 75 hours) exhibited significant difference ( $p<$ 0.05 ) between the $50 \mathrm{mg} \mathrm{l}^{-1}$ and the other two groups. There are significant differences between points that do not share the same letter. 


\section{Heart rate assessment}

Figure 4 presents the comparative boxplot of heart rate by $\mathrm{Cu}$ dilution for the control group and treated groups. We observed that the levels of $\mathrm{Cu}$ concentration resulted in significantly higher heart rates in embryos exposed to 50 and $0.05 \mathrm{mg} \mathrm{l}^{-1}$, showing higher heart rates at 6 hours after hatching for each experimental group compared to the non-exposed to $\mathrm{Cu}$ embryos of the control group. Kruskal-Wallis non-parametric post hoc analysis among heart rate and types of $\mathrm{Cu}$ dilution showed that $\mathrm{Cu}$ induced higher levels of heart rate. According to the above, the control group's heart rate was substantially lower than $50 \mathrm{mg}$ $\mathrm{l}^{-1}(p=0.002)$ and $0.05 \mathrm{mg} \mathrm{l}^{-1}(p=0.008)$ group (Table $3)$. The two groups containing $\mathrm{Cu}$ did not significantly differ from one another $(p=0.795)$.

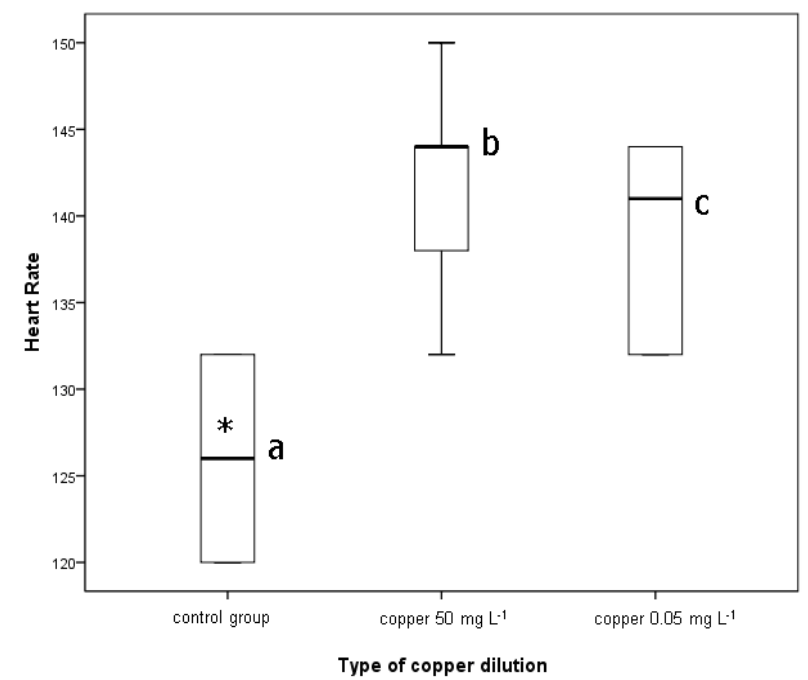

Figure-4: Comparative Boxplot of Heart Rate by Copper Dilution. Different letters indicate significant differences $(p<0.05$; Kruskal-Wallis non-parametric post hoc test).

Table-3: Multiple Comparisons of heart rate among different treatments.

\begin{tabular}{|c|c|c|}
\hline $\begin{array}{c}\text { Treatment (Median } \\
\text { Range) }\end{array}$ & $\begin{array}{c}\text { Heart Rate } \\
\text { Mean Rank }\end{array}$ & $\begin{array}{c}\text { P value vs } \\
\text { Control } \\
\text { Group }\end{array}$ \\
\hline $\begin{array}{c}\text { Control Group } \\
(126.00,12)\end{array}$ & 4.00 & - \\
\hline $\begin{array}{c}\text { Copper sulphate } \mathrm{CuSO}_{4}, \\
50 \mathrm{mg} \mathrm{l}^{-1}(144.00,18)\end{array}$ & 13.17 & $\mathbf{. 0 0 2}$ \\
\hline $\begin{array}{c}\text { Copper sulphate } \mathrm{CuSO}_{4}, \\
0.05 \mathrm{mg} \mathrm{l}^{-1}(141.00,12)\end{array}$ & 11.33 & $\mathbf{. 0 0 8}$ \\
\hline
\end{tabular}

Kruskal Wallis non parametric post hoc analysis.

\section{Discussion}

There was a noticeable effect of $\mathrm{Cu}$ on all the monitored parameters in the present study. Survival, pathology, metabolism, and growth were affected by increasing concentrations of $\mathrm{Cu}$. Mortality varied according to developmental stage and $\mathrm{Cu}$ concentration. Within the first 6 hours after fertilisation, we observed high mortality of fertilised eggs at the highest tested concentration of $\mathrm{Cu}(500 \mathrm{mg}$ $1^{-1}$ ). Also, compared to the control group, we observed delayed embryonic development of embryos exposed to concentrations of $50 \mathrm{mg} \mathrm{l}^{-1}$.

These results are in agreement with previous studies reporting that $\mathrm{Cu}$ inhibits pre-hatch embryonic development (Bai et al., 2010; Almond and Trombetta, 2016; Mohammadbakir, 2016). $\mathrm{Cu}$ can inhibit hatching (Johnson et al., 2007), and delay hatching in various species of fish (Mohammadbakir, 2016) and fish embryos exposed to $\mathrm{Cu}$ (Jezierska et al., 2009). Moreover, according to Almond and Trombetta (2016), there is a direct correlation between hatching ability, time, and exposure and the ability of hatching is dose-dependent. Furthermore, the data of viability for developing embryos support proportional hazards assumption for the use of the Cox Proportional Hazards model, with not crossing curves for each treatment (McLaskey et al., 2016).

Similar results were observed even after exposure at lower $\mathrm{Cu}$ concentrations and in most cases, the highest mortality levels are exhibited within the first 24 hours PSF (Hernández et al., 2006; Hen Chow and Cheng, 2003), but the survival and magnitude of the effect vary in fish species and $\mathrm{Cu}$ concentration. According to Johnson et al. (2007), exposure to $\mathrm{Cu}$ during the first 24-hour PSF (hpf) in zebrafish (Danio rerio) resulted in delayed embryonic development and high mortality.

The results of the current study supports previous studies showing that exposure to $\mathrm{Cu}$ significantly decreased the survival of zebrafish embryos, particularly during the stages of gastrulation and segmentation (Johnson et al., 2007), with lethal and sub-lethal effects of environmental chemicals varying between the pre-hatch and post-hatch stages in zebrafish (Horie et al., 2017) and the concentration of the heavy metals (Ganesan et al., 2016).

In agreement with previous studies (Cheng et al., 2000; Villeneuve et al., 2014; Horie et al., 2017), the results of the present work indicate that exposure of embryos to $\mathrm{Cu}$ led in embryonic and larval anatomical 
and functional defects. Pathological effects of $\mathrm{Cu}$ were present in all the experimental groups exposed to $\mathrm{Cu}$, with skeletal malformations and pericardial edema as well as elevated heart rate. A significant observed effect of $\mathrm{Cu}$ was the morphological abnormalities, severe pericardial edema, spine curvature, posterior body scoliosis, caudal tip malformation, and abnormal fattening of the posterior part in zebrafish embryos. These results are in agreement with reported pathological problems after exposure to $\mathrm{Cu}$, such as teratogenicity of $\mathrm{Pb}^{2+}$ and $\mathrm{Cu}^{2+}$ on zebrafish embryos, including bent spine, double tail spine, pericardial edema, and yolk sac edema, while several kinds of malformations often appeared together in one larva ( $\mathrm{Li}$ et al., 2015; Sfakianakis et al., 2015; Zhang et al., 2015; Almond and Trombetta, 2016; Ganesan et al., 2016).

Exposure to $\mathrm{Cu}$ significantly affected embryonic development, with groups exposed to $\mathrm{Cu}$, exhibiting lower rates of utilisation of yolk sac nutrient reserves. Embryonic metabolism relies on the utilisation of yolk reserves and can be adequately supported by oxygen diffusion during the pre-hatch stage via inward oxygen diffusion and outward carbon dioxide diffusion through the zona radiate (Nathanailides, 1996). After hatching, diffusion of respiratory gasses is facilitated via the skin and can adequately support the post-hatching metabolic requirements of developing zebrafish embryos (Pelster and Burggren, 1996). The rate of yolk absorption is an indication of the embryonic metabolism of developing fish. Yolk converts to body mass, and fast conversion rate indicates an elevated metabolic rate (Rombough, 1988). In other words, under optimal conditions, fish will efficiently and rapidly convert yolk reserved to body weight and environmental variables such as pollutants can impair this process (Peterson et al., 1983).

The results of the present work indicate that pre-hatch embryonic development indicates a significant effect of each tested $\mathrm{Cu}$ concentration with significant differences between each group. In embryos exposed to levels of 50 $\mathrm{mg} \mathrm{l}^{-1}$ and above, we noted decreased hatching success and reduced rate of embryonic growth. Compared to the control and $0.05 \mathrm{mg} \mathrm{l}^{-1}$, the $50 \mathrm{mg} \mathrm{l}^{-1}$ exhibited significantly delayed hatching. In the same manner, we observed the effects of $\mathrm{Cu}$ exposure on the metabolism of developing zebrafish in post-hatching stages. For example, groups exposed to $\mathrm{Cu}$ exhibited lower rates of utilisation of yolk sac nutrient reserves at $\mathrm{Cu}$ concentration as low as $0.05 \mathrm{mg} \mathrm{l}^{-1}$.
In assessing the toxicity of $\mathrm{Cu}$ on developing zebrafish embryos, we used a range of different parameters. The copper-induced alterations of heartbeat rate observed in the present study are in agreement with previously published results for zebrafish embryos and larvae affected by toxic compounds, reporting that larvae exposed to $\mathrm{Cu}$ exhibited significantly increased heart rates compared to the control groups (D'amico et al., 2012; Mohammadbakir, 2016; Horie et al., 2017). The cellular mechanism of this may involve a stress response in the larvae (Barton, 2011), such as impaired aerobic metabolism with consequent effect on the cardiovascular system, resulting in an increased heart rate and, possibly, as the present results indicate, subsequent pericardial edema (Barrionuevo et al., 2010). Cardiovascular, respiratory and metabolic functions may exhibit developmental plasticity according to environmental parameters, including temperature, oxygen, and heavy metals (Nathanailides, 1996; Jezierska et al., 2009). Consequently, the toxic effect of $\mathrm{Cu}$ on zebrafish may involve a wider range of physiological processes with varying sensitivity to $\mathrm{Cu}$ according to different stages of development.

Interestingly sub-lethal toxic effects of $\mathrm{Cu}$ were manifested in heartbeat rate well before other monitored parameters of sub-lethal effects become significantly different in all the groups. The heartbeat rate can be an early sign and a reliable indicator in assessing the severity of $\mathrm{Cu}$ toxicity for developing zebrafish with minimal laboratory equipment and resources. This protocol may be easily strengthened by specialised image analysis software for automatic zebrafish heartbeat detection and analysis (Pylatiuk et al., 2014; Kang et al., 2018), reducing time and resources for initial evaluation of $\mathrm{Cu}$ toxicity on developing zebrafish. It would be interesting to validate this method in other fish species or environmental pollutants for potential reduction of required resources and experimental animals in pilot experiments for toxicological research.

\section{Conclusion}

The results of the present study indicate changes of physiological parameters and toxic effects of Copper on the zebrafish embryos which are important for the assessment of water toxicity and the role of heavy metals in aquatic ecosystems and their impact on aquatic organisms. Also, the heartbeat rate of the developing embryos can is a reliable indicator of the 
effect of toxicity on the zebrafish. Heartbeat rate may be used as a rapid and convenient criterion for initial screening of toxicological evaluation of $\mathrm{Cu}$ on fish embryos or in sighting studies for determining appropriate starting concentration for further toxicological research.

\section{Ethical statement}

All fish studies have been approved by the appropriate ethics committee, and have therefore been performed in accordance with the ethical standards laid down in the 1964 Declaration of Helsinki and its later amendments (Number of ethical permission: 33/0704-2016).

\section{Disclaimer: None.}

\section{Conflict of Interest: None.}

Source of Funding: None.

\section{References}

Almond KM and Trombetta LD, 2016. The effects of copper pyrithione, an antifouling agent, on developing zebrafish embryos. Ecotoxicol. 25(2): 389-398.

Bai W, Tian W, Zhang Z, He X, Ma Y, Liu N and Chai $Z, 2010$. Effects of copper nanoparticles on the development of zebrafish embryos. J. Nanosci. Nanotechnol. 10(12): 8670-8676.

Barrionuevo WR, Fernandes MN and Rocha O, 2010. Aerobic and anaerobic metabolism for the zebrafish, Danio rerio, reared under normoxic and hypoxic conditions and exposed to acute hypoxia during development. Braz. J. Biol. 70(2): 425434.

Barton BA, 2011. Stress in finfish: Past, present and future-a historical perspective, pp. 1-34. In G.K. Iwama, A.D. Pickering, J.P. Sumpter and C.B. Schreck, (eds) Fish stress and health in aquaculture (Seminar Series Vol. 62). Cambridge University Press, UK.

Bashir MA, Javed M, Latif F and Ambreen F, 2018. Effects of various doses of copper sulphate on peroxidase activity in the liver, gills, kidney and brain of Cirrhina mrigala. Asian J. Agric. Biol. 6(3): 367-372.

Brand M, Granato M and Nósslein-Volhard C, 2002. Keeping and raising zebrafish, pp. 7-38. In C. Nósslein-Volhard and R. Dahm (eds) Zebrafish: a practical approach. Oxford University Press, Oxford, UK.
Cheng SH, Wai AWK, So CH and Wu RSS, 2000. Cellular and molecular basis of cadmium-induced deformities in zebrafish embryos. Environ. Toxicol. Chem. 19(12): 3024-3031.

D'amico LS, Seng Wl, Yang Y and Suter W, 2012. Assessment of drug induced cardiotoxicity in zebrafish, pp. 45-54. In P. McGrath (eds) Zebrafish: Methods for Assessing Drug Safety and Toxicity. John Wiley \& Sons, Inc, New Jersey, USA.

Dave G and Xiu R, 1991. Toxicity of mercury, copper, nickel, lead, and cobalt to embryos and larvae of zebrafish, Brachydanio rerio. Arch. Environ. Contam. Toxicol. 21(1): 126-134.

De Boeck G, Van der Ven K, Hattink J and Blust R, 2006. Swimming performance and energy metabolism of rainbow trout, common carp and gibel carp respond differently to sublethal copper exposure. Aquat. Toxicol. 80(1): 92-100.

Finn RN, 2007. The physiology and toxicology of salmonid eggs and larvae in relation to water quality criteria. Aquat. Toxicol. 81(4): 337-354.

Flemming CA and Trevors JT, 1989. Copper toxicity and chemistry in the environment: a review. Water Air Soil Pollut. 44(1-2): 143-158.

Ganesan S, Anaimalai Thirumurthi N, Raghunath A, Vijayakumar S and Perumal E, 2016. Acute and sub-lethal exposure to copper oxide nanoparticles causes oxidative stress and teratogenicity in zebrafish embryos. J. Appl. Toxicol. 36(4): 554567.

Gellert G and Heinrichsdorff JAN, 2001. Effect of age on the susceptibility of zebrafish eggs to industrial wastewater. Water Res. 35(15): 3754-3757.

Gouva E, Nathanailides C, Paschos I, Athanassopoulou F and Pappas IS, 2019. Sublethal and lethal effects of copper on developing zebrafish embryos. Proceedings of the 41st EEBE Scientific Conference, Katerini, Greece. Pp. 8182.

Hen Chow ES and Cheng SH, 2003. Cadmium affects muscle type development and axon growth in zebrafish embryonic somitogenesis. Toxicol. Sci. 73(1): 149-159.

Hernández PP, Moreno V, Olivari FA and Allende ML, 2006. Sub-lethal concentrations of waterborne copper are toxic to lateral line neuromasts in zebrafish (Danio rerio). Hear. Res. 213(1-2): 1-10.

Hernandez PP, Undurraga C, Gallardo VE, Mackenzie N, Allende ML and Reyes AE, 2011. 
Sublethal concentrations of waterborne copper induce cellular stress and cell death in zebrafish embryos and larvae. Biol. Res. 44(1): 7-15.

Horie Y, Yamagishi T, Takahashi H, Shintaku Y, Iguchi T and Tatarazako N, 2017. Assessment of the lethal and sublethal effects of 20 environmental chemicals in zebrafish embryos and larvae by using OECD TG 212. J. Appl. Toxicol. 37(10): 1245-1253.

Jezierska B, Lugowska K and Witeska M, 2009. The effects of heavy metals on embryonic development of fish (a review). Fish Physiol. Biochem. 35(4): 625-640.

Johnson A, Carew E and Sloman KA, 2007. The effects of copper on the morphological and functional development of zebrafish embryos. Aquat. Toxicol. 84(4): 431-438.

Kang CP, Tu HC, Fu TF, Wu JM, Chu PH and Chang DTH, 2018. An automatic method to calculate heart rate from zebrafish larval cardiac videos. BMC Bioinformatics. 19(1): 169.

Lee J, Prohaska JR and Thiele DJ, 2001. Essential role for mammalian copper transporter Ctr1 in copper homeostasis and embryonic development. Proceed. Natl. Acad. Sci. 98(12): 6842-6847.

Li Y, Yang X, Chen Z, Zhang B, Pan J, Li X and Sun $\mathrm{D}, 2015$. Comparative toxicity of lead $\left(\mathrm{Pb}^{2+}\right)$ copper $\left(\mathrm{Cu}^{2+}\right)$ and mixtures of lead and copper to zebrafish embryos on a microfluidic chip. Biomicrofluidics. 9(2): 024105.

Linbo TL, Stehr CM, Incardona JP and Scholz NL, 2006. Dissolved copper triggers cell death in the peripheral mechanosensory system of larval fish. Environ. Toxicol. Chem. 25(2): 597-603.

Mackenzie NC, Brito M, Reyes AE and Allende ML, 2004. Cloning, expression pattern and essentiality of the high-affinity copper transporter 1 (ctr1) gene in zebrafish. Gene. 328:113-120.

McLaskey AK, Keister JE, McElhany P, Olson MB, Busch DS, Maher M and Winans AK, 2016. Development of Euphausia pacifica (krill) larvae is impaired under pCO2 levels currently observed in the Northeast Pacific Mar. Ecol Progr. Ser. 555: 65-78.

Mielke H, Strickland J, Jacobs MN and Mehta JM, 2017. Biometrical evaluation of the performance of the revised OECD Test Guideline 402 for assessing acute dermal toxicity. Regul. Toxicol. Pharmacol. 89: 26-39.

Milanov ĐR, Krstić PM, Marković VR, Jovanović AD, Baltić MB, Ivanović SJ and Baltić ŽM, 2016.
Analysis of heavy metals concentration in tissues of three different fish species included in human diet from Danube River. Acta Vet. 66(1): 89-102.

Mohammadbakir S, 2016. Impacts of waterborne copper and silver on the early life stage (ELS) of zebrafish (Danio rerio): physiological biochemical and molecular responses $(\mathrm{PhD}$ Thesis) University of Plymouth, UK. https://pearl.plymouth.ac.uk

Mount DI, 1968. Chronic toxicity of copper to fathead minnows (Pimephales promelas Rafinesque). Water Res. 2(3): 215-223.

Mu X, Pang S, Sun X, Gao J, Chen J, Chen X and Wang C, 2013. Evaluation of acute and developmental effects of difenoconazole via multiple stage zebrafish assays. Environ. Pollut. 175: 147-157.

Nathanailides C, 1996. Metabolic specialization of muscle during development in cold-water and warm water fish species exposed to different thermal conditions. Can. J. Fisher. Aquat. Sci. 53(9): 2147-2155.

Parichy DM, Elizondo MR, Mills MG, Gordon TN and Engeszer RE, 2009. Normal table of postembryonic zebrafish development: staging by externally visible anatomy of the living fish. Devel. Dynam. 238(12): 2975-3015.

Pelster B and Burggren WW, 1996. Disruption of hemoglobin oxygen transport does not impact oxygen-dependent physiological processes in developing embryos of zebra fish (Danio rerio). Circ. Res. 79(2): 358-362.

Peterson RH, Metcalfe JL and Ray S, 1983. Effects of cadmium on yolk utilization, growth, and survival of Atlantic salmon alevins and newly feeding fry. Arch. Environ. Contam. Toxicol. 12(1):37-44.

Pylatiuk C, Sanchez D, Mikut R, Alshut R, Reischl M, Hirth S and Just S, 2014. Automatic zebrafish heartbeat detection and analysis for zebrafish embryos. Zebrafish. 11(4): 379-383.

Rombough PJ, 1988. Growth, aerobic metabolism, and dissolved oxygen requirements of embryos and alevins of steelhead, Salmo gairdneri. Canadian J. Zool. 66(3): 651-660.

Rubinstein AL, 2006. Zebrafish assays for drug toxicity screening. Expert Opin. Drug Metab. Toxicol. 2(2): 231-240.

Sfakianakis DG, Renieri E, Kentouri M and Tsatsakis AM, 2015. Effect of heavy metals on fish larvae deformities: a review. Environ. Res. 137: 246255. 
Stallard N, Whitehead A and Indans I, 2003. Statistical evaluation of the fixed concentration procedure for acute inhalation toxicity assessment. Hum. Exp. Toxicol. 22(11): 575-585.

Suvarchala G and Philip GH, 2016. Toxicity of 35 6trichloro-2-pyridinol tested at multiple stages of zebrafish (Danio rerio) development. Environ. Sci. Pollut. Res. 23(15): 15515-15523.

Villeneuve D, Volz DC, Embry MR, Ankley GT, Belanger SE, Léonard M, Schirmer K, Tanguay $\mathrm{R}$, Truong $\mathrm{L}$ and Wehmas L, 2014. Investigating Alternatives to the fish early-life stage test: A strategy for discovering and annotating adverse outcome pathways for early fish development. n. Toxicol. ChemEnviro. 33(1): 158-169.

Von Westernhagen H, 1988. Sublethal effects of pollutants on fish eggs and larvae. In: Hoar W, Randall DJ (eds) The physiology of developing fish. Fish physiology II. Academic Press, New York, USA. pp. 253-346.
Yang X, Liu Y, Li J, Chen M, Peng D, Liang Y and Jiang G, 2016. Exposure to Bisphenol AF disrupts sex hormone levels and vitellogenin expression in zebrafish. Environ. Toxicol. 31(3): 285-294.

Zhang T, Xu L, Wu JJ, Wang WM, Mei J, Ma XF and Liu JX, 2015. Transcriptional responses and mechanisms of copper-induced dysfunctional locomotor behavior in zebrafish embryos. Toxicol Sci. 148(1): 299-310.

\section{Contribution of Authors}

Gouva E: Designed and performed experiments, analysed data and co-wrote the paper.

Nathanailides C: Designed and supervised experiments, analysed data and co-wrote the paper.

Paschos I: Designed and supervised experiments Athanassopoulou F: Designed and supervised the experiment and co-wrote the paper. Pappas IS: Designed and supervised the experiment and co-wrote the paper. 